ROCZNIKI PEDAGOGICZNE

Tom 13(49), numer $3-2021$

DOI: http://doi.org/10.18290/rped.21133.8

MAGDALENA MACIEJEWSKA

\title{
NIEWIDOMI WE WSPÓLNOCIE RELIGIJNEJ. POTRZEBY I TRUDNOŚCI
}

\begin{abstract}
WSTĘP
Człowiek - niezależnie od wielu czynników, takich jak stan zdrowia lub stopień sprawności - nieustannie stara się realizować kolejne cele. W przypadku osób zmagających się z niepełnosprawnością niektóre wyzwania mogą nieco różnić się od tych, które są podejmowane przez osoby w pełni sprawne. Wynika to zarówno ze specyfiki funkcjonowania w danym środowisku, jak i istniejących w społeczeństwie barier o charakterze infrastrukturalnym, technologicznym lub społecznym. Warto wobec tego zastanowić się nad tym, czy katalog potrzeb, których zaspokojenie jest konieczne dla prawidłowego funkcjonowania człowieka, różni się w przypadku osób sprawnych oraz zmagających się z rozmaitymi dysfunkcjami. W związku z tym, że człowiek jest istotą społeczną i to właśnie w społeczeństwie ma możliwość urzeczywistniania rozmaitych dążeń, w przypadku niniejszego artykułu zostanie to zawężone do konkretnego fragmentu rzeczywistości dotyczącego sfery duchowej.

Pomimo postępującego procesu laicyzacji w społeczeństwie wciąż dostrzegalne jest duże zainteresowanie tematami okołoreligijnymi, co pokazuje, że potrzeba odkrywania sensu istnienia świata, siebie samego i poszukiwania odpowiedzi na egzystencjalne pytania - w przypadku niektórych osób $\mathrm{w}$ powiązaniu $\mathrm{z}$ religią, a $\mathrm{w}$ przypadku innych $\mathrm{w}$ oderwaniu od niej - jest bardzo silna.
\end{abstract}

Mgr Magdalena MacieJEwSKA - Interdyscyplinarna Szkoła Doktorska Nauk Społecznych Uniwersytetu Mikołaja Kopernika; adres do korespondencji: Fosa Staromiejska 1a, 87-100 Toruń; e-mail: magdalena.kalina.zajac@onet.pl; ORCID: https://orcid.org/0000-0001-8523-3310. 
Potrzeba duchowości stanowi fakt antropologiczny, ponieważ jest związana z naturą ludzką, dlatego każda osoba, niezależnie od pochodzenia i religii, odczuwa potrzebę życia duchowego. Człowiek rozwijając siebie, realizując powierzone zadania, odkrywa w sobie wyższe potrzeby i chce je zaspokoić. Tęsknota za pełnią, przekraczanie swoich ograniczeń wyraża się w pragnieniu rozwijania ducha, by odnaleźć wewnętrzną harmonię i pokój (Głowiński, 2013, s. 104).

Ten rodzaj potrzeby może być zaspokajany na różne sposoby w zależności od tego, czy duchowość jest powiązana z religijnością, czy też nie. Ponadto relacja z Absolutem dla niektórych ludzi ma charakter stricte indywidualny i nie ma w niej miejsca na wspólnotę, dla innych zaś wiąże się z koniecznością obcowania z ludźmi o podobnej hierarchii wartości. Taką możliwość - w przypadku duchowości o charakterze religijnym - stwarzają wspólnoty religijne, które poza tym, że umożliwiają realizowanie potrzeb o charakterze duchowym, stwarzają także szansę na rozwój społeczny i osobowy jednostki.

Struktura niniejszego artykułu przedstawia się następująco: w pierwszej części przedstawiono najważniejsze kwestie związane $\mathrm{z}$ rozwojem duchowym człowieka $z$ niepełnosprawnością, w drugiej zaś znalazły się refleksje dotyczące wspólnoty jako miejsca służącego duchowemu rozwojowi. W kolejnych dwóch częściach zaprezentowane zostały wyniki badań własnych, czyli analiza fragmentów przeprowadzonych wywiadów, co pozwoliło na zdiagnozowanie potrzeb i trudności, których doświadczyły badane osoby z niepełnosprawnością wzrokową zaangażowane w działalność wspólnot religijnych.

\section{ROZWÓJ DUCHOWY CZŁOWIEKA Z NIEPEŁNOSPRAWNOŚCIĄ}

Człowiek, zmagający się z trudnościami, początkowo stara się przede wszystkim w racjonalny sposób znaleźć wyjaśnienie zaistniałego stanu rzeczy i problemów, które pojawiły się w jego życiu. Jedną z funkcji duchowości - według M. Zwierżdżyńskiego - jest „transcendowanie czasoprzestrzeni”, czyli nadawanie znaczeń rozmaitym doświadczeniom mającym miejsce w życiu człowieka (Zwierżdżyński, 2010, s. 81). To szczególnie istotne dla osób zmagających się z rozmaitymi niepełnosprawnościami - w przypadku niniejszego artykułu uwaga zostanie skoncentrowana na niepełnosprawności wzrokowej. Istnieją rozmaite kryteria dotyczące jej podziału, które uwzględniają takie czynniki, jak m.in. ostrość wzroku, pole widzenia, przyczyny uszkodzenia itd. (Sękowska, 2001, s.100; Walthes, 2007, s. 41). Według klasyfi- 
kacji M. Kupisiewicz do grona osób niewidomych zalicza się tych, u których „W wyniku diagnozy medycznej stwierdzono ostrość wzroku wynoszącą nie więcej niż 0,1 pełnej ostrości wzroku (która odpowiada wartości 1,0) lub pole widzenia, niezależnie od ostrości wzroku, wynoszące najwyżej $30^{\circ}$ pełnego pola widzenia (ok. $180^{\circ}$ )" (Kupisiewicz, 2013, s. 219). Z kolei osobami słabowidzącymi są ci, u których ,występują poważne ograniczenia możliwości korzystania z informacji o charakterze wizualnym [...], zaburzenia ostrości widzenia mieszczące się $\mathrm{w}$ przedziale od 0,06 do 0,25 pełnej ostrości wzroku; ubytki w polu widzenia; zaburzenia wrażliwości na światło, obniżenie wrażliwości na kontrast [...] i inne" (tamże, s. 330-331). Mając na uwadze kryterium wspominane przez niektórych respondentów, czyli czas wystąpienia niepełnosprawności, wyróżnia się osoby niewidome i ociemniałe. W tej pierwszej grupie znajdują się osoby zmagające się z niepełnosprawnością od wczesnego dzieciństwa lub od urodzenia, zaś w drugiej znajdują się osoby, które straciły wzrok po ukończeniu 5. roku życia (Sękowska, 2001, s. 98).

Utrata zmysłu, który odpowiada za dostarczanie ok. 80\% informacji z otoczenia (Sokołowska-Kasperiuk, 2015, s. 156), najczęściej jest dla człowieka zdarzeniem traumatycznym, prowadzącym do bardzo dużych zmian w kontekście codziennego funkcjonowania. W związku z tym u wspomnianych osób często pojawiają się pytania dotyczące sensu cierpienia oraz własnego istnienia, które są ściśle związane $\mathrm{z}$ duchową sferą życia człowieka. Samą duchowość niegdyś utożsamiano z pojęciem religijności, aczkolwiek obecnie coraz częściej są one prezentowane jako dwa odrębne terminy. Psychologiczne, społeczne oraz religijne pojmowanie duchowości - pokazujące zarazem, jakże złożona jest to kwestia - łączy jednak termin „relacja” pojawiający się w większości subdyscyplinarnych charakterystyk duchowości. Może on oznaczać zarówno intymność i pełną zaufania bliskość w odniesieniu do drugiego człowieka oraz Boga, zaś w kontekście samego siebie można go rozumieć jako dogłębne poznanie swoich motywacji oraz lęków, czyli tego, co często pozostaje nieodkryte, a jest istotne w kontekście osobowego i duchowego rozwoju człowieka.

Umiejętność budowania relacji oraz znajomość własnego potencjału i słabości stanowią jeden z czynników odpowiedzialnych za wspomniany już rozwój osobowy człowieka dojrzałego. Jest to szczególnie istotne ze względu na fakt, że świadome rozwijanie własnej duchowości w pożądanym kierunku może nastąpić wówczas, gdy równolegle następuje proces budowania własnej dojrzałości. Dzięki temu relacje: ja-on/ona oraz ja-inni, do których 
dochodzi w rozmaitych wspólnotach, bazują na określonej przez jednostkę hierarchii wartości, na jej przyczyniających się do rozwoju społeczności zaletach oraz walce $\mathrm{z}$ własnymi słabościami. Duchowość bowiem wymaga odnoszenia się do świata zewnętrznego, prezentowania wewnętrznych przekonań przy jednoczesnej weryfikacji ich trwałości i stopnia ugruntowania (Chmielewski, 1999, s. 11-12). To pokazuje, że duchowość nie jest czymś niewymagającym pracy, bowiem aby mogła wkroczyć na poziom charakteryzujący człowieka dojrzałego, konieczny jest wysiłek mający na celu refleksyjną analizę zasłyszanych lub pozornie przyjmowanych zasad.

Sama duchowość ma dwa wymiary - pragmatyczny i niepragmatyczny które odgrywają bardzo ważną rolę w kontekście osób z niepełnosprawnością. Pierwszy z nich skupia się na poszukiwaniu osobistej satysfakcji poprzez medytację, praktyki religijne lub oddziaływanie poprzez sztukę, co przyczynia się do zwiększonej akceptacji własnej niepełnosprawności. Równie ważną rolę pełni jednak religijne zaangażowanie - stanowiące niepragmatyczny wymiar duchowości - bowiem pomaga osobom z niepełnosprawnością w pogodzeniu się z wystąpieniem danej dysfunkcji (Socha, 2000, s. 14). Odkrywanie sensu własnych ograniczeń i cierpienia prowadzi nie tylko do biernego pogodzenia się z zaistniałym stanem rzeczy, ale także do podjęcia działań, które w wielu przypadkach nie mogłyby zaistnieć, gdyby nie wystąpienie określonej dysfunkcji. Taka postawa stanowi nie tylko przejaw rozeznawania życiowej drogi, określanej także mianem powołania, ale także symptom rozwiniętej samoświadomości pozwalającej na odkrycie potencjału tkwiącego w tym zmysłowym ograniczeniu.

Istnieją także dwa główne wymiary religijnego zaangażowania pomagającego $\mathrm{w}$ radzeniu sobie $\mathrm{z}$ niepełnosprawnością. Pierwszy z nich, określany mianem formy pasywnej, polega na obciążeniu Boga swoimi problemami i odrzuceniu myśli o ich samodzielnym rozwiązywaniu. Alternatywę stanowi forma aktywna, która wymaga większego zaangażowania w kontakt $\mathrm{z}$ Bogiem m.in. poprzez indywidualne lub wspólnotowe praktyki religijne. Budowana przez osoby zmagające się z niepełnosprawnością - wzrokową lub jakąkolwiek inną - więź z Bogiem może mieć charakter bezpośredni lub pośredni. To właśnie przy tej drugiej szczególnie przydatni są przewodnicy duchowi i wspólnoty religijne. Wybór formy zależy od wielu czynników, takich jak temperament, styl osobowości, sposób nawiązywania kontaktów, ale także od oczekiwań dotyczących znaczenia duchowości w życiu osoby z niepełnosprawnością. Ponadto w literaturze wyróżnia się dwa podejścia do wiary w kontekście osób zmagających się z trudnościami - problemowe ma miejsce wówczas, gdy osoba jest skupiona na danej trudności i szuka sposobów jej 
rozwiązania, emocjonalne zaś pojawia się wtedy, gdy dany człowiek szuka w wierze emocjonalnego wsparcia (Janocha, 2011, s. 57). Istnieją także trzy rodzaje pozytywnych mechanizmów odnoszących się do religijnego radzenia sobie z sytuacją trudną. Pierwszy z nich określa się mianem duchowego wsparcia religijnego i jego podwalinę stanowi przekonanie o Bożej opiece dającej poczucie bezpieczeństwa i pozwalającej poradzić sobie z danym problemem. Drugi to wsparcie ze strony Kościoła jako wspólnoty, co odnosi się do zaufania osobom związanym z Bogiem i stanowiącym wsparcie dla jednostki. Trzeci zaś jest przekazaniem woli Bożej odpowiedzialności za doświadczaną niepełnosprawność, co oznacza nie tyle negatywne emocje związane $\mathrm{z}$ poczuciem nadmiernego obciążenia, ale przekonanie o codziennym towarzystwie Bożej obecności w kontekście doświadczeń wynikających z danej niepełnosprawności (Pargament, 1997, s. 200-232).

O tym, że temat związany z relacjami pomiędzy duchowością i religijnością a niepełnosprawnością jest niezwykle istotny świadczy mnogość prowadzonych $\mathrm{w}$ tym zakresie badań dotyczących nie tylko osób $\mathrm{z}$ dysfunkcją wzroku. Według wielu badaczy jakość życia i gotowość do walki z chorobą lub niepełnosprawnością pozostaje $\mathrm{w}$ związku $\mathrm{z}$ dobrostanem duchowym, który stanowi swoistą barierę ochronną przed poczuciem beznadziejności i popadaniem w rozpacz (Seeman, Dubin, Seeman, 2003; Powell, Shahabi, Thoresen, 2003, Thoresen, 1999). Istnieje jednak wiele obszarów związanych ze zdrowiem i religijnością oraz duchowością człowieka, które wciąż pozostają nieodkryte. W związku $\mathrm{z}$ tym wciąż projektowane są nowe badania mające uzupełnić istniejące luki i zlikwidować wątpliwości z nimi związane. To właśnie w tym celu m.in. skonstruowano narzędzie BMMRS, za pomocą którego próbowano odpowiedzieć na pytanie, czy faktycznie u osób z rozmaitymi dysfunkcjami oraz chorobami (badano m.in. osoby z nowotworami i uszkodzeniem rdzenia kręgowego) następuje wzrost poziomu religijności/duchowości. Według tamtejszych wyników możliwość radzenia sobie z podstawowymi zadaniami życiowymi i poziom bólu mają duży wpływ na poziom religijności. Znaczny spadek wiary widoczny jest głównie u osób zmagających się z poważnymi schorzeniami lub niepełnosprawnościami, tzn. takimi, które powodowały istotne, uniemożliwiające zwyczajne funkcjonowanie deficyty fizyczne, emocjonalne, poznawcze lub społeczne. Wystąpienie dysfunkcji lub zaburzenia nie wiąże się jednak - według tamtejszych badań $\mathrm{z}$ automatycznym zwrotem ku sferze duchowo-religijnej, co może mieć związek z utrudnionym dostępem do strefy związanej z duchowymi praktykami (J.D. Campbell, D.P. Yoon, B. Johnstone, 2010, s. 11-13). 
Dostępność do miejsc związanych ze sferą religijno-duchową jest szczególnie istotna zważywszy na fakt, że jedną z przestrzeni, istotnych dla rozwoju duchowego, stanowią wspólnoty, które tworzone są przez wiele różniących się od siebie podmiotów. Uczestnictwo w nich oznacza nie tylko konsekwentne zaangażowanie w realizowanie dobra wspólnego, ale przede wszystkim gotowość poznania i akceptacji „drugiego”, któremu przypisane zostały te same przymioty, co ,ja". Wyjątkowość tego wymiaru, określonego mianem „ja-drugi”, polega na tym, że opiera się on na dwóch głównych zasadach: jednokierunkowości i wzajemności, przy czym zrozumienie drugiego człowieka nie może zaistnieć bez odwoływania się do własnych doświadczeń, przeżyć, odczuć. Drugi wymiar - określany pojęciem „my” - zwraca uwagę na powiązanie funkcjonujących w ramach jednej wspólnoty podmiotów, które stanowi dobro wspólne (Ecler-Nocoń, 2017, s. 288-289). Zaangażowanie w działanie na jego rzecz umożliwia realizowanie samego siebie, wykorzystywanie swojego potencjału, zmaganie się ze słabościami oraz zwraca uwagę na to, że to nie przedmiot wyboru, ale sama decyzja o uczestnictwie stanowi klucz do zrozumienia sensu istnienia wspólnot o rozmaitym charakterze nie tylko tych religijnych.

Człowiek we wspólnocie nie jest skazany tylko na wypełnianie wybranych przez siebie zadań, ale ma możliwość jej współtworzenia opierającej się na szczególnie silnych, spajających daną zbiorowość więziach. Jest to możliwe dzięki temu, że:

to osoba rodzi wspólnotę, a nie odwrotnie, albowiem osoba ludzka nie jest jakimś wytworem układów społecznych, zależnym od ich zmienności. Wyraża się to w stwierdzeniu «osoba przed wspólnotą» - w sensie ontycznym, ale «osoba dla wspólnoty» - w sensie etycznym (Pokrywka, 2000, s. 79).

Mając na uwadze omawiane wcześniej przenoszenie własnych doświadczeń $z$,ja” na „drugiego” można poddać refleksji to, czy rola twórcza nie przyczynia się poprzez wzbudzenie poczucia realnej sprawczości i odpowiedzialności do uwrażliwienia poszczególnych członków wspólnot na potrzeby innych. Związana $\mathrm{z}$ tym zasada pomocniczości zwraca uwagę na to, że empatia i chęć służenia drugiemu człowiekowi nie może jednak przybierać formy uzależniającej lub pozbawiającej innej osoby autonomii i sprawczości.

Przynależność do rozmaitych wspólnot rozbudza w człowieku coraz bardziej marginalizowaną potrzebę przywiązania oraz poszukiwania bezpiecznego miejsca w świecie: 
istotą wspólnoty są sentymenty żywione dla innych ludzi, świata i siebie samego.
Wspólnota jest zjawiskiem stopniowalnym, jej siłę określa poziom doświadczania
przez członków poczucia solidarności oraz istotności. W rzeczywistości zdomino-
wanej przez indywidualizację człowiek uwikłany w sieć globalnych powiązań i zale-
żności traci możliwość «zakorzenienia», poszukuje wspólnoty, która byłaby «bez-
pieczną przystanią»w codziennym trudzie stawania się (Cudowska, 2009, s. 211).

Charakterystyczne dla czasów postmodernistycznych unikanie przywiązania oraz zobowiązań moralnych przyczynia się do tego, że ludzie, poszukujący miejsc postrzeganych w kategorii trwałych i bezpiecznych, narażeni są na niebezpieczeństwo nieodróżniania wspólnot niezgodnych z ich definicją, czyli pozbawiających członków autonomii oraz ograniczających ich kontakty ze światem zewnętrznym. Prawidłowo funkcjonująca wspólnota pozwala członkom na dzielenie się swoimi doświadczeniami i przemyśleniami także wówczas, gdy są one odmienne od pozostałych. Jest to źródłem dodatkowej refleksji, a zarazem weryfikacji swoich poglądów. Ponadto przynależność do wspólnoty i obcowanie z jej członkami pozwala człowiekowi zastanowić się nad tym, w jaki sposób uzasadnia normy moralne, na których opiera podejmowane przez siebie decyzje.

Możliwość kreowania wspólnotowej przestrzeni pozwalającej na realizowanie samego siebie jest zobowiązaniem, które nakłada na siebie człowiek decydujący się na wstąpienie do wspólnoty. Zróżnicowana sprawność, potrzeby i możliwości poszczególnych członków stanowią wartość dodaną w aspekcie rozwoju danej grupy, a obecność osób z niepełnosprawnościami pozwala spojrzeć na codzienność z innej perspektywy, przy jednoczesnym rozbudzeniu wrażliwości i rozeznawaniu potrzeby pomocy.

\section{METODOLOGIA BADAŃ WŁASNYCH}

Przedmiotem przeprowadzonego w kwietniu i maju 2020 r. badania był rozwój duchowy osób z niepełnosprawnością wzrokową zaangażowanych w działalność wspólnot religijnych. Ze względu na poważne trudności związane z sytuacją epidemiologiczną na terenie kraju zdecydowano się na przeprowadzenie rozmów telefonicznych z 10 respondentami zmagającymi się z dysfunkcjami wzroku, którzy kiedykolwiek przynależeli do wspólnot religijnych. Dziewięć osób było członkami facebookowej grupy „Niewidomi i Niedowidzący - Bądźmy razem", z kolei dziesiąta została zgłoszona za pośrednictwem znajdującej się na tym samym portalu społecznościowym grupy 
„Osoby niewidome i słabowidzące”. Długość rozmów telefonicznych, które nagrywano, wahała się pomiędzy 45 a 90 minutami. W tabeli 1. umieszczono podstawowe informacje o samych respondentach (imiona zostały zmienione).

Tabela 1. Charakterystyka respondentów

\begin{tabular}{|c|c|c|c|}
\hline Imię & Wyznanie & Wspólnota & $\begin{array}{c}\text { Rodzaj niepelnosprawności } \\
\text { wzrokowej }\end{array}$ \\
\hline Adam & katolickie & $\begin{array}{c}\text { Katolicka Wspólnota } \\
\text { Odnowy w Duchu Świętym } \\
\text { Gałąź Sykomory }\end{array}$ & osoba słabowidząca \\
\hline Alicja & baptystyczne & $\begin{array}{l}\text { Kościół Chrześcijan } \\
\text { Baptystów „Droga } \\
\text { Zbawienia” }\end{array}$ & osoba ociemniała \\
\hline Anna & katolickie & $\begin{array}{l}\text { Wspólnota Odnowy w Duchu } \\
\text { Świętym w Laskach, } \\
\text { Postakademicka Grupa } \\
\text { Odnowy w Duchu Świętym } \\
\text { Kyrios }\end{array}$ & osoba niewidoma \\
\hline Karol & katolickie & $\begin{array}{c}\text { Wspólnota Odnowy w Duchu } \\
\text { Świętym, Ruch Wiara i } \\
\text { Światło, Szkoła Nowej } \\
\text { Ewangelizacji }\end{array}$ & - \\
\hline Kornel & katolickie & $\begin{array}{c}\text { Akademicka Wspólnota } \\
\text { Ewangelizacyjna „Woda } \\
\text { Życia” oraz wspólnota osób } \\
\text { niepełnosprawnych działająca } \\
\text { w Warszawie przy kościele } \\
\text { św. Dominika }\end{array}$ & osoba ociemniała \\
\hline Lucyna & katolickie & $\begin{array}{c}\text { wspólnota modlitewna } \\
\text { u warszawskich dominikanów }\end{array}$ & - \\
\hline Sylwia & zielonoświątkowe & $\begin{array}{l}\text { Kościół Zielonoświątkowy } \\
\text { Zbór Chrystusa Zbawiciela }\end{array}$ & - \\
\hline Marta & katolickie & Odnowa w Duchu Świętym & osoba ociemniała \\
\hline Robert & katolickie & $\begin{array}{c}\text { Oaza Młodych w Krościenku, } \\
\text { Lednica } 2000\end{array}$ & - \\
\hline Szczepan & katolickie & $\begin{array}{l}\text { zgromadzenie zakonne } \\
\text { pallotynów }\end{array}$ & osoba ociemniała \\
\hline
\end{tabular}

Można zauważyć, że wśród badanych znaleźli się zarówno protestanci, jak i katolicy, u których całkowita lub znaczna utrata wzroku następowała w różnych okresach życia. W przypadku, gdy rozmowa o przyczynach lub czasie wystąpienia problemów ze wzrokiem miała dla respondenta bolesny 
charakter, badająca decydowała się na porzucenie tego wątku i przejście do właściwej części badania, tzn. oscylującej wokół rozwoju duchowego.

Prowadząca badania, decydując się na prowadzenie ich w strategii jakościowej, postanowiła skorzystać z metody indywidualnych przypadków ze względu na kilka elementów. Metoda ta jest wykorzystywana w ramach badań pedagogicznych m.in. ze względu na to, że pozwala na „dogłębne poznanie sytuacji życiowej danej osoby lub małych grup osób w kontekście wybranych czynników kulturowych, społecznych i edukacyjnych modyfikujących tę sytuację" (Domagała-Zyśk, 2016, s. 508), co w kontekście badań skoncentrowanych na kwestii bardzo osobistej wywoływało wiele emocji. Równie adekwatna byłaby tutaj metoda wywiadu, zwłaszcza mając na uwadze to, że badaczka nie analizowała dokumentów ani nie dokonywała dodatkowo obserwacji, jednakże warto zaznaczyć, że ich wykorzystanie nie jest warunkiem koniecznym, metoda ta bowiem - według przyjętej klasyfikacji M. Łobockiego - jest jedną z odmian metod biograficznych (Lobocki, 2009, s. 31) i może w kontekście kwestii wrażliwych opierać się wyłącznie na przeprowadzonych wywiadach.

Skorzystanie z techniki wywiadu pogłębionego pozwoliło skupić się na kwestiach szczególnie istotnych w kontekście problemu badawczego, czyli potrzeb i trudności, doświadczanych przez respondentów zmagających się $\mathrm{z}$ niepełnosprawnością wzrokową i zaangażowanych $\mathrm{w}$ działalność wspólnot religijnych. Wywiady pogłębione okazują się adekwatne zwłaszcza wówczas, gdy prowadzone badania oscylują wokół zagadnień związanych z kwestiami aksjologicznymi, religijnymi i światopoglądowymi.

Rozmowy z respondentami bazowały na przygotowanym wcześniej narzędziu badawczym zawierającym dyspozycje do wywiadu. Pozwoliły one na poruszenie $\mathrm{w}$ rozmowie kwestii związanych $\mathrm{z}$ czterema głównymi obszarami: relacjami z Bogiem, relacjami z samym sobą, relacjami międzyludzkimi i relacjami z niewymienionymi wcześniej elementami świata zewnętrznego. Dyspozycje te pozostawiały jednak respondentom wiele swobody, co umożliwiło badaczowi zwrócenie uwagi na obszary, które wydawały się nieistotne, a które dokładnie omawiali badani.

\section{POTRZEBY OSÓB NIEWIDOMYCH ZWIĄZANE Z FUNKCJONOWANIEM WE WSPÓLNOCIE}

Analiza uzyskanych wyników badań zwraca uwagę na to, że przynależność do wspólnoty religijnej umożliwia rozmówcom zaspokajanie rozmaitych po- 
trzeb. Niektóre z nich skupiają się na samej jednostce, inne zaś zwrócone są $\mathrm{ku}$ reszcie społeczeństwa. Wśród potrzeb najczęściej wymienianych przez respondentów dominuje pragnienie odczuwania satysfakcji ze swojego życia $\mathrm{i} \mathrm{w}$ dużej mierze jest to związane $\mathrm{z}$ niską samooceną, którą próbuje się poprawiać za pomocą opinii innych na swój temat. Jedna z respondentek, Sylwia, mówiła o tym w następujący sposób:

Jak [...] widziałam np. [...] że ktoś ma skończone studia i wyższe wykształcenie, a ja mam tylko podstawówkę, [...] to sama siebie [...] poniżałam.

Dyskryminacja osób, zmagających się z niepełnosprawnościami, nie zachodzi więc wyłącznie $\mathrm{z}$ udziałem osób trzecich - jej autorami mogą być także sami zainteresowani. Była liderka Odnowy w Duchu Świętym, Marta, wskutek utraty wzroku zmagała się z nieakceptowaniem samej siebie i w jej przypadku przynależność do wspólnoty pełniła rolę terapeutyczną i prowadziła do zmiany myślenia o samej sobie:

Przedtem bałam się, że ktoś na mnie fuknie, że czegoś nie zobaczę i cały czas byłam zakompleksiona.

Do zmiany postrzegania samego siebie u respondentów przyczyniały się również odnoszone sukcesy, niekiedy zaś wystarczała sama możliwość zmierzenia się z nowymi wyzwaniami. Wykorzystywanie swojego potencjału, czy też potrzeba odkrywania mocnych stron - w opiniach rozmówców - były wyraźnie związane z zadowoleniem z jakości swojego życia. Zwróciła na to uwagę m.in. Alicja zajmująca się prowadzeniem szkółki niedzielnej w jednym ze zborów.

Akurat jestem w tej grupie, gdzie są pierwszoklasiści i przedszkolaki, i też mamy np. taki trudny przypadek [...]. Jest chłopiec, który ma ADHD i on jest taki naprawdę, że ciężko go w ogóle uspokoić. Potrafi co chwilę krzyczeć, mówić, przerywać, tulić się [...]. Jest trudno ogarnąć takiego małego chłopca, ale to też daje taką satysfakcję, że nawet z takim dzieciaczkiem można sobie poradzić.

$\mathrm{Z}$ odczuwalnym poziomem akceptacji w przypadku osób z niepełnosprawnością wzrokową koresponduje także poczucie bezpieczeństwa, które również znajduje się wśród potrzeb skoncentrowanych na ,ja”. W przypadku Katolickiej Wspólnoty Odnowy w Duchu Świętym Gałąź Sykomory, do której należał Adam, na budowanie odczuwanego poziomu akceptacji i bezpieczeństwa oddziaływała utożsamiana z wiekiem dojrzałość pozostałych członków: 
To prawda, że to nie jest młodzież, to nie są rówieśnicy [...], a przede wszystkim [...] ludzie w wieku 35-40 lat, którzy siłą rzeczy bardziej rozumieją problem niepełnosprawności [...]. Może jest to klucz do tego, że ja się tam dobrze czuję.

Katalog potrzeb skoncentrowanych na jednostce w przypadku zarówno osób sprawnych, jak i zmagających się z rozmaitymi niepełnosprawnościami, nie pozostaje zamknięty. To, co jest pożądane przez niektórych członków wspólnoty, niekoniecznie spotyka się z aprobatą pozostałych, czego przykładem mogą być rozbieżne stanowiska prezentowane przez Kornela i Roberta. Pierwszy z nich uważał, że do pokonywania własnej nieśmiałości oraz podnoszenia samooceny przyczynia się stwarzana przez wspólnoty religijne możliwość wygłaszania świadectw dotyczących swojego życia:

Właśnie to chyba wspólnota też trochę otwiera na to, że człowiek się ośmiela. U nas we wspólnocie kładzie się właśnie nacisk na to, aby były świadectwa wspólnotowiczów.

Odmienne zdanie miał jednak Robert, dla którego niezwykle istotne było to, aby pozostać osobą duchowo anonimową. Warto poddać refleksji powiązanie jego stanowiska $\mathrm{z}$ tym, że wspólnota $\mathrm{w}$ jego przypadku pozwalała na realizowanie muzycznej pasji i w niewielkim stopniu była traktowana przez niego jako źródło rozwoju w jakimkolwiek innym aspekcie:

W scholi będą mnie wszyscy słyszeć, ale nie będzie mnie nikt za bardzo widzieć. [...] Ja lubię się tak schować [...]. Podobało mi się ostatnie kazanie, które było na Eucharystii. Wygłaszało je dwóch księży, którzy w ogóle się nie przedstawili, nie wiem skąd byli. Wygłosili kazanie w takim stylu - wy nas nie znacie, my was nie znamy, nie wiemy, kto wy jesteście, nie wiecie, kto my jesteśmy. Jakby tak kazanie było od nikogo dla nikogo.

Przytoczone wypowiedzi respondentów pokazują, że potrzeby związane z podnoszeniem poczucia własnej wartości oraz kwestie dotyczące akceptacji samego siebie są bardzo ważnym wątkiem w kontekście niniejszych badań. Warto jednak zwrócić uwagę także na potrzeby skoncentrowane na drugim człowieku, do których zaspokajania dochodzi we wspólnocie religijnej. Obecność innych przede wszystkim pozwala uniknąć samotności, co nie tylko w przypadku osób zmagających się z niepełnosprawnością wzrokową jest bardzo ważne. Zakonnik Szczepan zwracał w kontekście tego uwagę na to, że podobną rolę pełnią także inne grupy społeczne. Podkreślał, że wymiar religijny nie powinien stanowić wyłącznego źródła zainteresowania drugim 
człowiekiem i jedynego tematu rozmów ze względu na potrzebę włączania wspólnoty do życia codziennego i nadawania jej także takiego wymiaru:

Tak jak w pracy miałem dość dużo osób, które antykościelnie podchodziły do życia, to rozmowy, spotkania [...], takie świadectwo [...] to też więcej dało, niż takie brutalne opiniowanie i krytykowanie. Bo czasami też trzeba pytać drugą osobę o jej przeżycia, problemy.

Takie włączanie wspólnoty religijnej do codziennych spraw w niektórych przypadkach przyczyniało się do tego, że ich członkowie zaczynali w większym stopniu dostrzegać obecność i działanie Boga w świecie. Zwróciło na to uwagę aż 3 rozmówców: Marta, Sylwia i Adam. Ten ostatni opowiadał o tym w następujący sposób:

To szczególnie wspólnota mi pokazała, może nawet nie modlitwa, nie Słowo Boże, ale wspólnota. Chyba najbardziej świadectwa ludzi i rozmowy z ludźmi [...] - nie tylko o tym, że mieli jakieś wielkie nawrócenie, ale że doświadczają tego działania Boga w codziennym życiu, nawet w błahych rzeczach, nawet takich, że ktoś opowiada, że stracił pracę, poszukiwał jej, bał się, a nagle ktoś dzwoni i okazało się, że ma inną ofertę i to wszystko z modlitwą było połączone. Takie proste przypadki pokazują, że jest Pan Bóg, że widzę Pana Boga w codziennym życiu i staram się to wykorzystywać.

Potrzeba angażowania wspólnot religijnych w sprawy związane nie tylko z kwestiami duchowymi, ale także codziennymi radościami i zmartwieniami uwidaczniała się także w realizowaniu przez wspólnoty funkcji integracyjno-rozrywkowej. Niektóre z nich organizowały na początku lub końcu spotkań formacyjnych uroczyste kolacje, które znane są pod nazwą agapy, o czym opowiadała m.in. Sylwia:

Co druga niedziela jest taka urodzinowa. Kto ma urodziny w danym miesiącu przynosi ciastka i jest taka agapa. [...] Jak nawet urodzin nie ma, to też jest jakieś ciastko, jakaś kawa, herbata.

Tego typu aktywności, które zaspokajają naturalną potrzebę człowieka dotyczącą dzielenia się swoją codziennością z innymi wiążą się jednak z pewnym ryzykiem dotyczącym prób zastępowania lub uatrakcyjniania sfery sacrum, na co zwrócił uwagę w kontekście wyboru miejsca spotkań wspólnoty Konrad:

Grupka mojego brata przenosi się na przykład do pobliskiej kawiarni. Wiadomo, że nie mogliby wszyscy się przenieść, więc to jest jakby limitowane. To ciekawsze 
niż samo spotkanie w kościele. [...] Jak chodziłem na spotkania grupki mojego brata, to oni tam rozmawiali o wszystkim, czy o pracy, czy o wyjazdach, planach wakacyjnych. [...] Tam było luźniej.

Analizując potrzeby osób zmagających się z dysfunkcjami w kontekście przynależności do wspólnot religijnych, warto zastanowić się także nad tym, jakie oczekiwania dotyczące ich funkcjonowania mają sami zainteresowani. Poza wspólnotami zrzeszającymi zarówno osoby sprawne, jak i z niepełnosprawnościami, do których $\mathrm{w}$ większości należeli rozmówcy, istnieją bowiem także duszpasterstwa dedykowane, do których zalicza się np. Krajowe Duszpasterstwo Osób Niewidomych. Zaskakujące są jednak negatywne opinie wielu respondentów, co jest związane z dużą potrzebą kontaktu także ze sprawnymi osobami oraz możliwością mierzenia się ze zwyczajnymi wyzwaniami przeznaczonymi dla szerokiego grona odbiorców. Temat ten podjął m.in. Andrzej:

$\mathrm{Z}$ jednej strony to wiadomo, byłbym tam rozumiany tak jak nigdzie indziej, ale $\mathrm{z}$ drugiej strony nie lubię czegoś takiego, potrzebuję kontaktu $\mathrm{z}$ osobami pełnosprawnymi [...] Nigdy w takie kręgi nie wchodziłem i nie wiem, powiem szczerze, jak takie duszpasterstwo funkcjonuje.

Nie oznacza to oczywiście, że wszelkiego rodzaju grupy, mające taki charakter, powinny zostać zlikwidowane (co jednak sugerował w kontekście Polskiego Związku Niewidomych Rafał oburzony przyznawanymi wewnątrz organizacji odznaczeniami mającymi miejsce - w jego opinii - za pieniądze osób płacących składki, które nie mogą liczyć na jakiekolwiek godne uwagi propozycje aktywności), bowiem sens ich istnienia opiera się na wewnętrznym zróżnicowaniu Kościoła i różnych ścieżkach wiary oraz duchowego rozwoju ludzi. Zwracała uwagę na to zarówno sceptycznie nastawiona względem tej idei Lucyna, jak i bardziej pozytywnie nastawiony do tej kwestii Szczepan, będący zarazem wiceprezesem Polskiego Związku Niewidomych.

Rzadko biorę udział w spotkaniach z duszpasterstwem niewidomych, ale jeśli komuś jest to potrzebne, komuś to pomaga w jego funkcjonowaniu, życiu, może niektórzy nie mają takich możliwości, kontaktów [...]. Jest to takie trochę zamknięte. (Lucyna)

Mi się wydaje, że w Kościele są różne wspólnoty i na tym też polega bogactwo Kościoła [...], że każdy się może w czymś odnaleźć. Jedni w oazie, drudzy w innych modlitwach [...] Nie muszę kogoś zmuszać, mogę siebie widzieć w danej wspólnocie, a Pani może widzieć siebie w innej i to jest piękne w Kościele. (Szczepan) 
Mając na uwadze mnogość wymienianych potrzeb, których zaspokajanie jest możliwe wewnątrz wspólnot religijnych, można stwierdzić, że w niektórych przypadkach taka grupa staje się niejako zastępczą rodziną, niekiedy bywając uzupełnieniem tej, do której rzeczywiście się należy, kiedy indziej zaś alternatywą dla niej. To w pewien sposób może uzasadniać występowanie potrzeb, które w wielu przypadkach zaspokajane są w rodzinach lub grupach przyjaciół, a także próby łączenia sfery sacrum ze sferą profanum.

\section{TRUDNOŚCI OSÓB NIEWIDOMYCH ZWIĄZANE Z FUNKCJONOWANIEM WE WSPÓLNOCIE}

Przynależność do wspólnoty religijnej nie może być rozpatrywana wyłącznie w kontekście potrzeb osób będących jej członkami, ale także wyzwań z tym związanych. W związku z tym jedno z pytań badawczych dotyczyło potrzeb osób zmagających się z niepełnosprawnością wzrokową, które chciały realizować $\mathrm{w}$ danej grupie, drugie zaś trudności, $\mathrm{z}$ jakimi w tym kontekście się zmagają. Aktywne uczestnictwo we wspólnocie religijnej w przypadku osób z niepełnosprawnością wzrokową łączy się bowiem z koniecznością pokonywania rozmaitych barier. Trudności te można podzielić na dwie grupy - pierwsza z nich ma charakter zewnętrzny, czego przykładem mogą być trudności związane $\mathrm{z}$ dostępem do miejsca spotkań. W drugiej zaś, mającej charakter wewnętrzny, znajdują się przekonania, stereotypy i obawy, których autorami mogą być albo członkowie wspólnoty lub sami zainteresowani. Zarówno jedne, jak i drugie mogą prowadzić albo do porzucenia zamiarów związanych z dołączeniem do wspólnoty lub zaprzestaniem podejmowania w niej różnych aktywności.

Stanowiące podstawę badań wywiady telefoniczne pozwoliły zwrócić uwagę na jedną z najważniejszych i często pojawiających się w wypowiedziach respondentów kwestię należącą do ograniczeń wewnętrznych. Korzystanie $\mathrm{z}$ nowych technologii tylko pozornie może wydawać się niezwiązane z duchowym rozwojem osób z niepełnosprawnością wzrokową, zwłaszcza w perspektywie panującej pandemii, o czym opowiadał m.in. Kornel:

Oglądam codziennie mszę świętą, więc też jest fajnie. Jestem niestety w grupie podwyższonego ryzyka przez choroby dodane, nie tylko to ociemnienie, więc korzystam jak najbardziej z nowych technologii [...] np. z czytań na smartfonie jak najbardziej. 
Niektórym respondentom nowe media sprawiają poważne trudności zarówno ze względu na ich niepełnosprawność, jak i na brak biegłości związanej z niedostępnymi dawniej rozwiązaniami technologicznymi. Na zmierzenie się z tym wyzwaniem zdecydowała się jednak Sylwia:

Ja się uczę, bo te grupy domowe są właśnie teraz przez kamery. I dopiero dwa razy były, ale już ponaciskałam nie to, co potrzeba... Mam trudności z zapamiętaniem, gdzie trzeba coś nacisnąć. To dla mnie jeszcze [...] nowość.

Z wieloma trudnościami, mającymi techniczny charakter, mierzyli się rozmówcy związani z muzyką. Robert, który potrafi grać na wielu instrumentach muzycznych i angażuje się w organizację spotkań lednickich, miał poważne problemy z zapisami do grupy muzycznej ze względu na weryfikujący tożsamość mechanizm opierający się na wyborze konkretnych obrazków. Adam z kolei zwrócił uwagę na niedostępność śpiewników religijnych dla osób niewidomych oraz na brak możliwości połączenia gry i śpiewu nowych utworów, które - w przypadku wcześniejszego przygotowania - może odczytywać za pomocą brajla. Pomimo tego, że jego rozwój muzyczny przez to jest w pewien sposób zahamowany, to nieustannie podejmuje on próby pokonania tej bariery, co wskazuje na silną motywację i zaangażowanie.

$\mathrm{Na}$ jedną z najbardziej zaskakujących trudności, której doświadczają osoby z niepełnosprawnością wzrokową, także zwrócił uwagę związany z muzyką Adam. Dotyczy ona dźwiękowej nadwrażliwości powodującej problemy ze skupieniem się w czasie praktyk o charakterze duchowym lub religijnym. Ten przypadek pokazuje, że nie zawsze wyostrzenie zmysłu może być rozpatrywane w kategorii specyficznych zalet.

\footnotetext{
Mam też duży problem ze skupieniem się. Myślę, że to się wzięło poniekąd z niepełnosprawności, z tego że nie widzę i że bardzo dużą uwagę poświęcam dźwiękom, bardzo często nieświadomie. [...] Dużą uwagę zwracam na akustykę pomieszczenia, więc jak jestem gdzieś w kościele, w którym jest duży pogłos, to ja się nie mogę skupić. Kościoły typu Kościół Mariacki, duże klasztory nie są dla mnie, bo jeżeli nie siądę wystarczająco blisko głośnika, to ten dźwięk jest rozmyty, nie trafia do mnie bezpośrednio, więc się rozpraszam. [...] Dla mnie najlepszym miejscem są takie malutkie kościółki, drewniane kaplice, gdzie jeśli ktoś jest naprawdę, to jest cicho mimo wszystko, dźwięk się nie odbija od ścian. Albo dom.
}

Brak brajlowskich oznaczeń i niedostateczne przygotowanie pod kątem infrastrukturalnym dostrzegalne są w wielu miejscach publicznych - także w kościołach. Na trudności związane z przyjmowaniem komunii podawanej bezgłośnie przez księdza oraz z poruszaniem się po mało znanej przestrzeni 
- pomiędzy ławkami, filarami, dekoracjami - zwrócił uwagę Karol. Dyskusyjną kwestią pozostaje także obecność w kościele psów przewodników, czemu - pomimo dokumentów to regulujących - wciąż sprzeciwiają się niektóre parafie, o czym opowiadał Robert, powołując się na historię swojego kolegi, który tego doświadczył:

On sobie wchodzi do kościoła, jest już nabożeństwo i nagle ten ojciec przerywa mszę i mówi do Pawła: „Proszę wyjść z tym psem!”. „Ale proszę ojca, to jest pies przewodnik”. „Proszę wyjść, natychmiast!”. Potem Paweł zadzwonił tam do nich i mówi: „Na jakiej podstawie zostałem wyrzucony z kościoła? W oparciu o jaką podstawę teologiczną?”. „Nie będę takiej rozmowy prowadził, to nieważne! I rzucił słuchawką, koniec rozmowy. A potem Paweł poszedł do dominikanów, a oni mówią mu tak: „Ooo, masz psa przewodnika, fajnie. Siądź sobie w pierwszym rzędzie, to ci będzie łatwiej do komunii chodzić”. [...] Episkopat Polski musiał wprowadzić do ustawy taki swój zapis, który mówi o tym, że z psami przewodnikami do kościoła wejść wolno. Bo tak to osoby takie były po prostu wypraszane z nabożeństw i już.

Wśród ograniczeń, mających charakter zewnętrzny, najczęściej wymienia się strach i niechęć innych - najczęściej sprawnych - przed stycznością z osobami zmagającymi się z niepełnosprawnościami. Najczęściej pojawia się on w okolicznościach niecodziennych, związanych np. z wyjazdem w nieznane miejsce. Ten lęk przed koniecznością dodatkowego zaangażowania i zmierzeniem się $\mathrm{z}$ własną niewiedzą oraz pytaniami uważanymi niekiedy przez osoby sprawne za krępujące, prowadzi do takiej sytuacji, jakiej doświadczyła Lucyna:

\footnotetext{
Potem był taki wyjazd w Bieszczady i ja się zgłosiłam, że chcę jechać. I zadzwonił ksiądz, który się nami opiekował i zapytał: „A to Ty masz jechać z nami?”. Powiedziałam: „No tak, właśnie się pakuję”. „A czy nie byłoby Ci przykro, jakbyś została sama w domu?”. „No tak, pewnie, nie... No to po co ja mam jechać...” I zrezygnowałam z tego wyjazdu [...]. Potem kolega powiedział: „Tam były takie przejścia i szlaki, sami nie wiedzieliśmy jak iść, to nie wiedzielibyśmy jak Ciebie poprowadzić". A dwa tygodnie później od franciszkanów właśnie był wyjazd, na którym było ileś osób niewidomych i pojechałam. I poszliśmy w góry - i można było! Jedna osoba mogła przeprowadzić kilka osób niewidomych, czasem trzeba było zaczekać, że się jedną osobę przeprowadzi, potem drugą, potem trzecią. Później nauczyłam się chodzić do tego naszego kościoła no i śpiewam w tej scholi.
}

Ten przykład pokazuje, że zwiększone zaangażowanie - w tym przypadku związane ze śpiewaniem w scholi - może być wynikiem działania o charakterze integracyjnym, które powoduje, że samoocena osoby z dysfunkcją wzroku nie ulega pogorszeniu wskutek odrzucenia i alienacji. Jest to szcze- 
gólnie ważne szczególnie ze względu na wspominane wcześniej problemy z poczuciem własnej wartości występujące u dużej części rozmówców. To właśnie dlatego nawiązywanie nowych kontaktów jest dla wielu z nich poważną barierą, o czym opowiadał m.in. Adam, który początkowo podczas wyjazdów starał się towarzyszyć wyłącznie bliskiej sobie osobie z obawy przed tym, że nie zostanie zaakceptowany przez innych. Na kwestię dotyczącą konieczności przyzwyczajania się do ciągłych zmian - zwłaszcza w przypadku życia zakonnego osoby z niepełnosprawnością wzrokową - zwraca uwagę Szczepan.

\footnotetext{
Osoby duchowne, które żyją we wspólnotach, mają też na pewno inne życie niż osoby, które żyją w rodzinach. I to są tego typu minusy, że [...] od czasu do czasu są zmiany w tego typu wspólnotach. Jeżeli ja, powiedzmy, mam tutaj współbraci dobrych i fajnych, którzy mi pomagają, to wiem, że za jakiś czas oni się zmienią, przejdą gdzieś indziej i przyjdą nowi. I każdemu muszę nie tyle tłumaczyć, co ukazać, na czym polega ich pomoc. Jeżeli miałbym żonę, dzieci, które byłyby przyzwyczajone w pewien sposób, to oni mieliby to we krwi, a tutaj trzeba za każdym razem od nowa wdrażać w temat.
}

Jego spostrzeżenie odnieść można jednak nie tylko do wspólnot zakonnych, ale także wielu innych, bowiem wkraczanie w każde nowe środowisko - zwłaszcza w takie, w którym zawiązuje się bliższe więzi - wiąże się z koniecznością wdrażania bliźnich $\mathrm{w}$ świat osób $\mathrm{z}$ niepełnosprawnościami. $\mathrm{W}$ innym przypadku trudno mówić o poczuciu bezpieczeństwa $\mathrm{w}$ danej wspólnocie, a w konsekwencji - o pragnieniu przynależności do niej.

\section{ZAKOŃCZENIE}

Osoby z niepełnosprawnością wzrokową decydują się na podejmowanie nowych aktywności w społeczeństwie, w związku z czym bardzo istotne jest danie im możliwości współtworzenia wspólnot religijnych. Rozmowy z respondentami pokazały, że towarzyszy im strach przed niepodołaniem nowym wyzwaniom związanym np. z przynależnością do danych wspólnot przy jednoczesnym pragnieniu rozwoju, które w wielu przypadkach związane jest z poszukiwaniem grupy odpowiedniej dla siebie. Należy zauważyć, że osoby badane przede wszystkim przejawiają aktywną formę i pośredni charakter swojego zaangażowania w funkcjonowanie Kościoła, co oznacza, że rola innych ludzi, dla których wiara jest ważna, jest dla nich istotna, bowiem pozwala na realizację wskazanego wcześniej w części teoretycznej podejścia 
emocjonalnego, polegającego znacznie bardziej na poszukiwaniu emocjonalnego wsparcia aniżeli rozwiązania konkretnych barier związanych z ich niepełnosprawnością.

Potrzeby wyróżnione przez osoby badane wskazują na to, iż bardzo ważną rolę pełni dla nich możliwość brania udziału w procesie podejmowania decyzji dotyczących zarówno ich samych, jak i wspólnoty, do której przynależą. Istotne jest bowiem nie tylko postrzeganie osób z niepełnosprawnością wzrokową w perspektywie jednostkowej, ale także zbiorowej. To oznacza, że bardzo ważne jest wykorzystywanie ich umiejętności oraz predyspozycji także na rzecz realizacji dobra wspólnego i działań podejmowanych przez całą wspólnotę. Wielu badanych zaznaczało, że zależy im na przynależności do grupy, której członkowie nie są wyłącznie osobami zmagającymi się z niepełnosprawnościami. W związku z tym należy zaznaczyć, że to nie tworzenie wspólnot wyłącznie dla osób z rozmaitymi dysfunkcjami powinno być kierunkiem dalszych działań, ale budowanie wspólnot o charakterze inkluzywnym, wewnętrznie zróżnicowanych m.in. pod względem płci, stopnia sprawności, czy też umiejętności i zainteresowań. Propozycją wartą zastanowienia jest również stworzenie w poszczególnych wspólnotach miejsca dla asystentów osób z niepełnosprawnościami, przypominających analogiczne stanowiska akademickie. Ich wiedza, umiejętności, chęci oraz predyspozycje mogłyby zostać wykorzystane w kontekście wdrażania do wspólnot osób zmagających się $\mathrm{z}$ niepełnosprawnością wzrokową i ich zaangażowania w poszczególne aktywności podejmowane przez całą grupę.

Niezwykle istotne jest podjęcie działań wynikających ze świadomości wymienionych przez respondentów trudności. Niektóre z nich - zwłaszcza te mające charakter wewnętrzny i odnoszące się do niskiej samooceny badanych - wymagają znacznie bardziej złożonych i wielokierunkowych działań. Jest to związane przede wszystkim z emocjonalnym funkcjonowaniem osób niewidomych i tym, że nieadekwatna samoocena czy też poczucie bycia gorszym są konsekwencją nieprawidłowości pojawiających się w procesie wychowania i socjalizacji (Sękowski, 2001, s. 66-69). Jednakże inne - związane przede wszystkim z ograniczeniami zewnętrznymi - możliwe są do usunięcia. Problemy związane $\mathrm{z}$ brakiem udogodnień infrastrukturalnych w miejscach, w których odbywają się spotkania wspólnot, można zlikwidować w taki sam sposób, w jaki czyni się to w innych miejscach publicznych. Brajlowskie oznaczenia na planach wskazujących lokalizację poszczególnych pomieszczeń lub rozmieszczenie przeszkód w nawach kościoła, śpiewniki z przynajmniej częścią tekstów zapisanych za pomocą pisma punktowego, 
czy też organizowanie spotkań popularyzujących wiedzę dotyczącą nie tylko komunikacji z osobami zmagającymi się z niepełnosprawnością wzrokową, ale także trudności, których doświadczają m.in. w środowisku kościelnym, to propozycje, które należałoby poddać rozwadze mając na uwadze to, że przynależność do wspólnot religijnych jest istotnym obszarem życia osób zmagających się $\mathrm{z}$ niepełnosprawnością wzrokową, który umożliwia im zaspokajanie rozmaitych potrzeb oraz zmaganie się z trudnościami, których nie zawsze mogą doświadczyć w innych środowiskach.

\section{BIBLIOGRAFIA}

CAmpBell, J.D., Yoon D.P., Johnstone B. (2010). Determining Relationships Between Physical Health and Spiritual Experience, Religious Practices, and Congregational Support in a Heterogeneous Medical Sample. Journal of Religion and Health, 49(1).

Chmielewski, M. (1999). Sto jeden pytań o życie duchowe. Lublin: Polihymnia.

CudowsKa, A. (2009). Wspólnota w kulturze indywidualizmu. W: J. Nikitorowicz, J. MuszyŃSKA, M. SOBECKI (red.), Wspólnoty z perspektywy edukacji międzykulturowej. Białystok: Trans Humana Wydawnictwo Uniwersyteckie.

DomAGAŁA-ZYŚK, E. (2016). Studium indywidualnego przypadku jako metoda badań naukowych w pedagogice specjalnej. W: R. Skrzyniarz, L. Dziaczkowska, D. Opozda (red.), Przedmiot, źródła i metody badań w biografii. Lublin: Wydawnictwo Episteme.

ECLER NoCOŃ, E. (2017). Wokół kategorii „uczestnictwa” - rozważania w perspektywie myśli społecznej Karola Wojtyły. Studia Edukacyjne, 46.

GŁowIŃSKI, M. (2013). Duchowość niepełnosprawnych, czyli życie w duchu błogosławieństw. Humaniora, 3.

JANOCHA, W. (2011). Religijność osób niepetnosprawnych i ich rodzin. Studium socjologiczno-pastoralne. Lublin: Wydawnictwo KUL.

KuPISIEWICZ, M. (2013). Stownik pedagogiki specjalnej. PWN: Warszawa.

Łoвоскі, M. (2009). Metody i techniki badań pedagogicznych. Kraków: Oficyna Wydawnicza Impuls.

MamajeK, A. (2009). Status ,prawdy” w postmodernizmie. Studia Elblaskie, 10.

Pargament, K.I. (1997). The Psychology of Religion and Coping. Theory, Research, Practise. New York: Guilford Press.

Powell, L.H., Shahabi, L., Thoresen, C.E. (2003). Religion and spirituality. Linkages to physical health. Am Psychol, 58.

Pokrywka, M. (2000). Osoba, uczestnictwo, wspólnota. Refleksje nad nauczaniem społecznym Jana Pawła II. Lublin: Redakcja Wydawnictw Katolickiego Uniwersytetu Lubelskiego.

Seeman, T.E., Dubin, L.F., SeEman, M. (2003). Religiosity/spirituality and health. A critical review of the evidence for biological pathways. Am Psychol, 58.

SĘKOWSKA, Z. (2001). Wprowadzenie do pedagogiki specjalnej. Warszawa: APS. 
SĘKOWSKI, T. (2001). Psychologiczne aspekty rehabilitacji zawodowej osób niewidomych zatrudnionych $w$ warunkach petnej $i$ częściowej integracji. Lublin: Wydawnictwo Uniwersytetu Marii Curie-Skłodowskiej.

Socha, P. (2000). Psychologia rozwoju duchowego - zarys zagadnienia. W: P. SochA (red.), Duchowy rozwój człowieka. Kraków: Wydawnictwo Uniwersytetu Jagiellońskiego.

SOKOŁOWSKA-KASPERIUM, A. (2015). Blaski i cienie życia dorosłej osoby ociemniałej w kontekście przystosowania się do niepełnosprawności. Studium przypadku. Interdyscyplinarne Konteksty Pedagogiki Specjalnej, 10.

THORESEN, C.E. (1999). Spirituality and Health: Is There a Relationship?. J Health Psychol, 4.

WALthes, R. (2007). Tyflopedagogika, tłum. J. Mink. Gdańsk: GWP.

WoJtyŁA, K. (2000). Osoba i czyn oraz inne studia antropologiczne. Lublin: Towarzystwo Naukowe Katolickiego Uniwersytetu Lubelskiego.

ZWIERŻDŻYŃSKI, M. (2010). Religia - duchowość - postmodernizm. Problem znaczeń. W: M. LIBISZOWSKA-ŻóŁtKowsKa, S. GrotowsKa (red.), Religijność $i$ duchowość - dawne i nowe formy. Kraków: Zakład Wydawniczy NOMOS

\section{NIEWIDOMI WE WSPÓLNOCIE RELIGIJNEJ. POTRZEBY I TRUDNOŚCI}

\section{STRESZCZENIE}

Celem artykułu, mającego charakter teoretyczno-empiryczny, jest zaprezentowanie potrzeb i trudności, których doświadczyły badane osoby z niepełnosprawnością wzrokową zaangażowane w działalność wspólnot religijnych. Szczególną uwagę zwrócono na potrzeby skoncentrowane na „ja” oraz potrzeby skoncentrowane na „ty”, a także na ograniczenia o charakterze zewnętrznym oraz wewnętrznym. W artykule zaprezentowano wyniki badań przeprowadzonych w oparciu o strategię jakościową, metodę indywidualnych przypadków i z wykorzystaniem techniki wywiadu pogłębionego. W gronie respondentów znalazło się 10 osób zmagających się z dysfunkcjami wzroku, które przynależą lub w przeszłości przynależały do wspólnot religijnych. W artykule rozpatrywano m.in. to, w jaki sposób bycie członkiem określonej grupy o charakterze religijnym umożliwiało realizację istotnych dla respondentów potrzeb, a także z jakimi ograniczeniami musieli się w związku z tym zmagać.

Słowa kluczowe: niewidomi; wspólnota; chrześcijaństwo; potrzeby; trudności.

\section{THE BLIND IN THE RELIGIOUS COMMUNITY. NEEDS AND DIFFICULTIES}

SUMMARY

The aim of the theoretical and empirical article is to present the needs and difficulties experienced by the surveyed persons with visual impairment involved in the activities of religious communities. Particular attention has been paid to 'me' and 'you' focused needs, as well as external and internal constraints. The article presents the results of research conducted on the basis 
of a qualitative strategy, the method of individual cases and the use of the in-depth interview technique. The group of respondents included 10 people struggling with sight dysfunctions who belong to or belonged to religious communities in the past. The article considered, inter alia, how being a member of a specific religious group made it possible to meet the needs of the respondents, and what limitations they had to deal with as a result.

Keywords: the blind; community; Christianity; needs; difficulties. 